\title{
Characterization of Bacteria and Inducible Phages in an Intensive Care Unit
}

\author{
Cátia Pacífico ${ }^{1,2}{ }^{\mathbb{D}}$, Miriam Hilbert ${ }^{1,2}$, Dmitrij Sofka ${ }^{1}$, Nora Dinhopl ${ }^{3}$, Ildiko-Julia Pap ${ }^{4}$, \\ Christoph Aspöck ${ }^{2,4}$ and Friederike Hilbert ${ }^{1, *}$ \\ 1 Department of Farm Animals and Veterinary Public Health, University of Veterinary Medicine, 1210 Vienna, \\ Austria \\ 2 Karl Landsteiner University of Health Sciences, 3500 Krems an der Donau, Austria \\ 3 Department of Pathobiology, University of Veterinary Medicine, 1210 Vienna, Austria \\ 4 Institute of Hygiene and Microbiology, University Clinic St. Pölten, 3100 St. Pölten, Austria \\ * Correspondence: friederike.hilbert@vetmeduni.ac.at; Tel.: +43-1-25077-3316
}

Received: 13 August 2019; Accepted: 8 September 2019; Published: 10 September 2019

check for updates

\begin{abstract}
Intensive care units (ICUs) are critical locations for the transmission of pathogenic and opportunistic microorganisms. Bacteria may develop a synergistic relationship with bacteriophages and more effectively resist various stresses, enabling them to persist despite disinfection and antimicrobial treatment. We collected 77 environmental samples from the surroundings of 12 patients with infection/colonizations by Escherichia coli, Staphylococcus aureus or Klebsiella spp. in an ICU in Austria. Surface swabs were tested for lytic phages and bacterial isolates for mitomycin C-inducible prophages. No lytic bacteriophages were detected, but S. aureus was isolated from the surroundings of all patients. About $85 \%$ of the colonies isolated from surface samples were resistant to antimicrobials, with $94 \%$ of them multidrug resistant. Two inducible temperate bacteriophages-myovirus vB_EcoM_P5 and siphovirus vB_SauS_P9-were recovered from two clinical isolates. Staphylococci phage vB_SauS_P9 lysed S. aureus isolates from the surface swabs collected from the surroundings of three patients. No transductants were obtained on propagation in phage-sensitive antimicrobial-resistant isolates. The two phages were sensitive to $0.25 \%(\mathrm{v} / \mathrm{v})$ of the disinfectant TPH Protect, which eliminated viable phages after $15 \mathrm{~min}$. Coliphage vB_EcoM_P5 was inactivated at $70^{\circ} \mathrm{C}$ and staphylococci phage vB_SauS_P9 at $60^{\circ} \mathrm{C}$ after $60 \mathrm{~min}$.
\end{abstract}

Keywords: bacteriophages; Staphylococcus aureus; Escherichia coli; intensive care unit; prophage induction

\section{Introduction}

The intensive care unit (ICU) has been defined as an "epicenter" of nosocomial infections. Most of these pathogens are involved in the development, propagation, and amplification of antimicrobial resistance [1,2]. Infections caused by bacteria resistant to antimicrobials are correlated with age, severity of disease, general debility, length of hospitalization, use of invasive devices, and recurrent antimicrobial treatment $[1,3,4]$. Medical equipment, environment, patients, and hospital staff may be contaminated by pathogenic or opportunistic bacteria [5], such as methicillin-resistant Staphylococcus aureus (MRSA) and carbapenem-resistant Enterobacteriaceae [1,6]. Hospital hygiene policies mandate personal hygiene, active surveillance of asymptomatic colonization [7], decolonization strategies [8], and in severe cases, single-room isolation of MRSA-harboring patients [9]. Patients with Enterobacteriaceae may be asymptomatic, as these bacteria can effectively colonize the human gut and have a natural role as commensal organisms. Decontamination, thus, relies on an appropriate disinfection regime to prevent the dissemination of pathogens and improve the outcome of treatment $[8,10]$. 
Data from the European Centre for Disease Prevention and Control show that healthcare-associated infections in hospitals cause more deaths in Europe than any other infectious disease [11]. Bacteriophages-bacterial viruses-have been isolated from the bacteria of septicemic patients and free phage particles have been detected in patients' blood at the onset of sepsis [12]. However, there have been a few studies on the ecological aspect of bacteriophages in clinical bacterial infections [12-14] or colonizations [15].

Phages are the most abundant members of the human virome, present in every community examined [16-18]. Their wide distribution in the environment impacts both viral diversification and the bacterial host, shaping microbial communities towards an expanded functional diversity of the ecosystems. Lytic phages kill their bacterial host cell through lysis, while temperate bacteriophages (or lysogenic phages) either integrate in the bacterial genome (forming a so-called prophage) or exist as a plasmid in the bacterial cytoplasm. In the event of environmental stress, functional prophages can be excised and enter a lytic cycle $[16,19,20]$. The existence of prophages in the bacterial genome acts as a supplementary gene pool of horizontally transferred genes that confers higher fitness to the bacteria, thanks e.g., to the presence of virulence genes, antimicrobial resistance genes and/or survival factors [21-24]. The resulting lysogenic bacteria can cause human diseases, such as Shiga-toxin induced hemolytic uremic syndrome due to phage-encoded endotoxins [25], staphylokinase, chemotaxis inhibitors, staphylococcal complement inhibitor, or factors associated with biofilm formation [26].

The development of high-throughput sequencing technologies has enabled the complete characterization of microbiomes, including not only bacteria [27] but also viruses [28], and attention is now turning to how the microorganisms interact with the environment and with one another. Nevertheless, previous work on colonization of the ICU by commensal and pathogenic bacteria [28-31] has not considered the role of bacteriophages. We report an investigation of important ICU pathogens and their phages in the surroundings of patients colonized/infected with S. aureus, K. oxytoca, K. pneumoniae, and E. coli. Two lysogenic isolates retrieved from patients were able to release prophages upon stimulation with mitomycin $\mathrm{C}$. The bacteriophages were tested for the ability to mediate the transfer of antimicrobial resistance genes from resistant bacteria identified in the vicinity of the patients to sensitive host strains.

\section{Materials and Methods}

\subsection{Intensive Care Unit}

Between February 2017 and March 2018, a total of 77 surface samples were collected from the surroundings of twelve patients (P1 to P12) in an ICU of a hospital in the region of Lower Austria. The floor of the ICU is cleaned and disinfected once a day, and after every contamination. The sanitary installations (toilets, sinks, and faucets) are cleaned once a day with a disinfecting sanitary cleaner. Surfaces far from patients and with frequent hand contact are disinfected once a day with a regular quaternary ammonium-based disinfectant (TPH Protect $0.5 \% \mathrm{v} / \mathrm{v}$ ). Surfaces in close contact with patients are disinfected at least twice a day and always after contamination, while devices are disinfected after each patient, at least twice a day and after contamination. Blankets and pillows are washed after contamination. In the event of Clostridia difficile colonization/infection, surfaces and floors are continuously disinfected with a sporocidal disinfectant (peracetic acid), and after regular hand disinfection, the staff is instructed to wash their hands with water and soap. The regular hand disinfectant is effective against Norovirus, but in the event of an infection with the virus, the surfaces are disinfected more frequently with the regular quaternary ammonium-based disinfectant (four times a day) and there is a terminal disinfection with peracetic acid.

The clinical isolates from patients P1 to P10 were collected (no clinical isolates were available from patients P11 and P12), together with relevant patient information. Additionally, 20 E. coli and 17 S. aureus isolates from stationary patients and outpatients in the hospital during the sampling period were included to test the bacteriophage host range (see Table 3). The study was performed in accordance 
with the Declaration of Helsinki and the institutional rules for Good Scientific Practice. The samples were anonymized and no confidential data from the patients was collected. Samples were collected from defined sites (pillow, breathing hose pole, blanket, bed rail, infusion bag, emergency/control button, dietary pump, side table, mattress topper, sheets, switch panel, feeding tube, and respiratory tube) using gel swabs (Transsystem ${ }^{\mathrm{TM}}$, COPAN, Brescia, Italy), liquid swabs (eSwab ${ }^{\mathrm{TM}}$, COPAN, Brescia, Italy), or surface wipes (Polywipe $₫$, MWE, Wiltshire, England) (Table 1). The samples were diluted in 1-3 mL of sterile $0.9 \% \mathrm{NaCl}$ (Merck, Darmstadt, Germany) and vortexed. The rinsed saline solution was used for the isolation of phages and bacteria. Bacterial cell counts were calculated per swab, or per wipe. The samples were collected prior to disinfection of the patient's surroundings and sent immediately for laboratory analysis.

Table 1. Type of sample, collection date, and number of sites analyzed for each patient (P1-P12).

\begin{tabular}{cccc}
\hline Patient ID & Type of Sample & Collection Date & Number of Sites \\
\hline P1 & Gel swab & 21.02 .17 & 5 \\
P2 & Gel swab & 21.02 .17 & 5 \\
P3 & Gel swab & 05.04 .17 & 6 \\
P4 & Gel swab & 11.05 .17 & 7 \\
P5 1 & Gel swab, liquid swab & 21.06 .17 & 6,6 \\
P6 & Liquid swab & 06.07 .17 & 6 \\
P7 & Liquid swab & 06.07 .17 & 6 \\
P8 & Liquid swab & 06.07 .17 & 6 \\
P9 & Liquid swab & 26.07 .17 & 5 \\
P10 & Liquid swab & 26.07 .17 & 5 \\
P11 & Surface wipe & 26.03 .18 & 6 \\
P12 & Surface wipe & 26.03 .18 & 8 \\
\hline
\end{tabular}

${ }^{1}$ The sites analyzed in P5 were replicated to compare both sampling methods. ${ }^{2}$ No isolates from the patient available.

\subsection{Isolation of Bacteria from Environmental Samples}

Isolates from E. coli were quantified on Coli-ID agar plates (bio-Mérieux, Marcy l'Etoile, France) and S. aureus on Aureus Agar Base HiCrome (Sigma-Aldrich, MO, USA) by plating $50 \mu \mathrm{L}$ of the rinsing solution. For the detection of the presumed resistant bacteria, five colonies were collected from each environmental sample and incubated for $24 \mathrm{~h}$ at $37^{\circ} \mathrm{C}$ on Mueller-Hinton agar (Oxoid Ltd., Basingstoke, UK) containing appropriate antimicrobials. E. coli were tested for resistance towards ampicillin at $35 \mu \mathrm{g} / \mathrm{mL}$, tetracycline at $20 \mu \mathrm{g} / \mathrm{mL}$, kanamycin at $30 \mu \mathrm{g} / \mathrm{mL}$, and chloramphenicol at $35 \mu \mathrm{g} / \mathrm{mL}$, while S. aureus were tested for penicillin-G at $0.5 \mu \mathrm{g} / \mathrm{mL}$, erythromycin at $4 \mu \mathrm{g} / \mathrm{mL}$, clindamycin at $1 \mu \mathrm{g} / \mathrm{mL}$, and tetracycline at $20 \mu \mathrm{g} / \mathrm{mL}$ (Sigma-Aldrich, St. Louis, MO, USA). The choice of antibiotics was based on their widespread use in veterinary and human medicine [32]. Disc diffusion was performed using the above-mentioned antimicrobials, according to the hospital's laboratory routine following guidelines of the European Committee on Antimicrobial Susceptibility Testing (EUCAST) [33] (see below). Resistant bacteria were re-cultured on AB-plates with appropriate antibiotics. The isolated bacterial colonies were stored in Modified Scholtens' Broth (MSB) or $2 \times$ Yeast Tryptone (YT) media with the addition of $20 \%(\mathrm{w} / \mathrm{v})$ glycerol (Sigma-Aldrich, St. Louis, MO, USA) at $-80{ }^{\circ} \mathrm{C}$.

\subsection{Lytic Bacteriophage Detection}

All 77 samples were tested for lytic bacteriophages infecting either E. coli or S. aureus according to ISO 10706-2:2000 [34], as described in [32,35]. Both E. coli DSM 12242 and S. aureus Sa9 [36] were used as indicator host strains for bacteriophage detection. An overnight culture of the indicator bacterium was used to inoculate a new broth and grown to an optical density of 0.4 at $600 \mathrm{~nm}$. One milliliter of the fresh bacterial culture and 1 milliliter of rinsed saline solution were added to $3 \mathrm{~mL}$ of preheated MSB, supplemented with $10 \mathrm{mM} \mathrm{CaCl}_{2}$. The mixture was vortexed and overlaid on Modified Scholtens' Agar (MSA) at room temperature. The solidified plates were incubated overnight at $37^{\circ} \mathrm{C}$. 


\subsection{Clinical Isolates from Patients}

Bacterial isolates and antibiograms were obtained for patients P1-P10. We did not evaluate whether patients were colonized or infected and isolates were not necessarily the cause of hospitalization (Table 2). Disc diffusion was performed according to the hospital's laboratory routine, following EUCAST guidelines [36]. For Enterobacteriaceae, we tested ampicillin (AM10), cefpodoxime (CPD10), cefuroxime (CXM30), cefotaxime (CTX5), ampicillin/sulbactam (SAM20), cefepim (FEP30), gentamicin (CN10), imipenem (IPM10), ceftazidime (CAZ10), meropenem (MEM10,) cefoxitin (FOX30), ciprofloxacin (CIP5), amikacin (AK30), and trimethropim (TMP5). S. aureus was tested for rifampicin (RA5), linezolid (LNZ10), mupirocin (MUP200), trimethropim (TMP5), fosfomycin (FF200), fusidic acid (FA10), minocyclin (MI30), gentamicin (CN10), erythromycin (E15), clindamycin (DA2), tetracycline (TE30), moxifloxacin (MXF5), cefoxitin (FOX30), penicillin G (P1), and tigecycline (TGC15).

Table 2. Clinical isolate, isolation source, and corresponding antibiogram.

\begin{tabular}{|c|c|c|c|c|c|}
\hline Patient ID & Bacterial Isolate & Isolation Source & Colony Count ${ }^{2}$ & Antibiogram & $\begin{array}{c}\text { Mitomycin } \\
\text { C-Inducible } \\
\text { Prophage }\end{array}$ \\
\hline P1 & S. aureus & Nose swab & +++ & Sensitive & - \\
\hline P2 & S. aureus & Trachea secretion & +++ & $\mathrm{P}^{\mathrm{R}}, \mathrm{MXF} \mathrm{R}^{\mathrm{R}}$ & - \\
\hline P3 & E. coli $^{1}$ & $\begin{array}{l}\text { Urine transurethral } \\
\text { catheter }\end{array}$ & $10^{7} / \mathrm{mL}$ & $\begin{array}{c}\mathrm{AM}^{\mathrm{R}}, \mathrm{SAM}^{\mathrm{R}}, \mathrm{CPD}^{\mathrm{R}}, \\
\mathrm{CTX}^{\mathrm{R}}, \mathrm{CXM}^{\mathrm{R}}, \mathrm{CIP}^{\mathrm{R}}, \mathrm{CN} \\
, \mathrm{TMP}^{\mathrm{R}}\end{array}$ & - \\
\hline P5 & E. coli & $\begin{array}{l}\text { Urine transurethral } \\
\text { catheter }\end{array}$ & $10^{7} / \mathrm{mL}$ & $\mathrm{AM}^{\mathrm{R}}, \mathrm{TMP}^{\mathrm{R}}$ & + \\
\hline P6 & K. pneumoniae & Trachea secretion & +++ & $\mathrm{AM}^{\mathrm{R}}$ & - \\
\hline P7 & K. pneumoniae ${ }^{1}$ & Trachea secretion & + & $\begin{array}{l}\mathrm{AM}^{\mathrm{R}}, \mathrm{SAM}^{\mathrm{R}}, \mathrm{CPD}^{\mathrm{R}}, \\
\mathrm{CTX}^{\mathrm{R}}, \mathrm{CXM}^{\mathrm{R}}, \mathrm{TMP}^{\mathrm{R}}\end{array}$ & - \\
\hline
\end{tabular}

${ }^{1}$ ESBL (extended-spectrum $\beta$-lactamase), CRE isolate; ${ }^{\mathrm{R}}$ stands for resistant. ${ }^{2}$ Colony counts were assessed either by direct counting or by indirect quantification using one "+" to " +++ ".

\subsection{Prophage Induction}

The ten bacterial isolates from each patient and a subset of bacteria $(n=73)$ collected from the environmental samples were tested for prophage induction using $0.5 \mathrm{mg} / \mathrm{mL}$ mitomycin C (AppliChem $\mathrm{GmbH}$, Darmstadt, Germany). Briefly, $40 \mathrm{~mL}$ of MSB media was inoculated with fresh bacteria and grown until an optical density of 0.4 at $600 \mathrm{~nm}$. At this point, 2 to $5 \mu \mathrm{g} / \mathrm{mL}$ mitomycin $C$ and $10 \mathrm{mM}$ $\mathrm{CaCl}_{2}$ were added and incubated for $2 \mathrm{~h}$. After incubation, the cells were supplemented with $10 \mathrm{mg} / \mathrm{mL}$ lysozyme (Sigma-Aldrich, St. Louis, MO, USA) to stimulate prophage release. The suspension was re-incubated and the supernatant collected after $24 \mathrm{~h}$. The supernatants were centrifuged for $5 \mathrm{~min}$ at $8000 \mathrm{~g}$ and plated following the soft-agar overlay method (as outlined above), using the native host (patient isolate, environmental isolate) and the indicator bacteria (S. aureus Sa9 or E. coli DSM 12242). A control without any inducing agent was included to test for spontaneous phage release.

\subsection{Bacteriophage Purification, Propagation, and Lysate Preparation}

Phage lysates were prepared according to Groisman [37]. Four individual plaques from each sample were retrieved from the soft agar layer and each suspended in $1 \mathrm{~mL}$ media. The solution was incubated at $37^{\circ} \mathrm{C}$ for $30 \mathrm{~min}$, further filtered through a $0.2 \mu \mathrm{m}$-pore filter and stored at $4{ }^{\circ} \mathrm{C}$. Bacteriophage suspensions were propagated by re-infection of the indicator host in triplicate using the purified lysate and the soft agar overlay method. After overnight incubation at $37^{\circ} \mathrm{C}$, the soft agar was shredded and $3 \mathrm{~mL}$ of media were added. The overlay was collected and centrifuged at $8000 \mathrm{~g}$ for $5 \mathrm{~min}$. The clear supernatant was filtered through a $0.2 \mu \mathrm{m}$-pore filter and kept at $4{ }^{\circ} \mathrm{C}$. Tenfold serial dilutions $\left(10^{-1}\right.$ to $\left.10^{-6}\right)$ were prepared and $10 \mu \mathrm{L}$ of the diluted lysate was plated with the indicator 
bacteria. After overnight incubation at $37^{\circ} \mathrm{C}$, the plaques were counted and the titer expressed as $\mathrm{PFU} / \mathrm{mL}$.

\subsection{Transmission Electron Microscopy (TEM)}

To prepare the phage for transmission electron microscopy (TEM), a droplet of the purified phage suspension $\left(10^{7}-10^{8} \mathrm{PFU} / \mathrm{mL}\right)$ was deposited on a copper grid (Science Services, Munich, Germany) with carbon-coated Formvar film for $10 \mathrm{~min}$ at room temperature and stained with $4 \%$ aqueous phosphotungstic acid (Merck, Darmstadt, Germany) at pH 7. After air drying overnight, the sample was observed with the Zeiss TEM 900 electron microscope (Carl Zeiss, Oberkochen, Germany) operated at $50 \mathrm{kV}$, using Image SP software and a CCD camera (TRS, Tröndle Restlichtverstärkersysteme, Moorenweis, Germany).

\subsection{Host Range Analysis}

Phages vB_EcoM_P5 and vB_SauS_P9 were tested for the ability to lyse the patient isolates collected during this study, bacterial collection strains, and clinical isolates from stationary patients and outpatients (see Table 3). Host range was determined by spot assay. A volume of $0.2 \mathrm{~mL}$ of stationary phase cell suspension was mixed with $3 \mathrm{~mL}$ of Molten-soft agar supplemented with $10 \mathrm{mM} \mathrm{CaCl}$, poured into a MSB or $2 \times Y \mathrm{~T}$ agar plate. After solidification, $0.02 \mathrm{~mL}$ of a $10^{7} \mathrm{PFU} / \mathrm{mL}$ phage suspension was spotted on the overlay and incubated at $37^{\circ} \mathrm{C}$ overnight. Phage vB_SauS_P9 was also tested in the S. aureus colonies isolated from the environmental samples taken during the study $(n=150)$.

\subsection{Determination of Efficiency of Plating (EOP)}

Bacterial lysis was confirmed by calculating the efficiency of plating (EOP) regarding the indicator host S. aureus Sa9 or E. coli DSM 12242 (EOP =1.0). A new bacterial host culture was prepared as above. One $\mathrm{mL}$ of host culture and $0.01 \mathrm{~mL}$ of a $10^{7} \mathrm{PFU} / \mathrm{mL}$ phage suspension were added to $3 \mathrm{~mL}$ of preheated MSB supplemented with $10 \mathrm{mM} \mathrm{CaCl}_{2}$. The mixture was vortexed, overlaid on MSA at room temperature, and incubated overnight at $37^{\circ} \mathrm{C}$. EOP was defined as the ratio between $\mathrm{PFU} / \mathrm{mL}$ on the sensitive bacteria and the $\mathrm{PFU} / \mathrm{mL}$ on the indicator strain. The bacteria were graded by their level of sensitivity as "high" (EOP $\geq 0.5)$, "medium" $(0.1 \leq \mathrm{EOP}<0.5)$, "low" $(0.001 \leq \mathrm{EOP}<0.1)$, and "inefficient" (EOP $\leq$ 0.001).

\subsection{Bacteriophage Transduction}

Bacteriophage transduction of vB_EcoM_P5 was performed using E. coli DSM 12242 as a host. Briefly, $100 \mu \mathrm{L}$ of an overnight culture was mixed with $10 \mu \mathrm{L}$ of phage lysate and incubated at $37^{\circ} \mathrm{C}$ for $30 \mathrm{~min}$ to permit phage absorption. Two milliliters of MSB was added and the mixture was incubated at $37^{\circ} \mathrm{C}$ for 1 to $2 \mathrm{~h}$ with shaking. The tubes were centrifuged at $8000 \mathrm{~g}$ for $3 \mathrm{~min}$. The supernatant was discarded, and the pellet suspended in $150 \mu \mathrm{L}$ MSB and plated on Mueller-Hinton agar plates containing ampicillin at $35 \mu \mathrm{g} / \mathrm{mL}$. Incubation was performed for approximately $48 \mathrm{~h}$ at $37^{\circ} \mathrm{C}$. As bacteriophage vB_SauS_P9 was derived from an AB-sensitive S. aureus, it was first propagated in two different antibiotic-resistant isolates from the environment of $\mathrm{P} 5$, with resistance against penicillin G, erythromycin, and clindamycin to possible resistance genes to be transduced. The new lysates of vB_SauS_P9 were used for transduction, as described above. The suspended pellet was plated on Mueller-Hinton agar containing $0.5 \mu \mathrm{g} / \mathrm{mL}$ penicillin- $\mathrm{G}, 4 \mu \mathrm{g} / \mathrm{mL}$ erythromycin, and $1 \mu \mathrm{g} / \mathrm{mL}$ clindamycin. 


\subsection{Disinfectant, Ethanol and Thermal Stability Tests}

Phage stability was determined in the presence of common hospital disinfectants, TPH Protect and Hexaquart ${ }^{\circledR}$ plus, at concentrations of $0.25 \%$ and $0.5 \%$. Phage preparations of $107 \mathrm{PFU} / \mathrm{mL}$ were incubated at room temperature and phage titer was determined at $0,15,30$ and 60 min by serial dilutions tested on the indicator strain by means of the soft agar overlay method. The phage particles were counted after overnight incubation at $37^{\circ} \mathrm{C}$. Assays were performed in duplicate. Survival to $70 \%$ ethanol and temperature stability $\left(25,37,45,44,60,65\right.$ and $\left.70{ }^{\circ} \mathrm{C}\right)$ was examined after $60 \mathrm{~min}$ incubation, as described elsewhere [38]. None of the conditions we tested affected the bacterial host strain, and phage infection was not impeded.

\section{Results}

\subsection{Bacterial and Viral Contamination}

Staphylococcus aureus was detected in the vicinity of all 12 patients, independent of the bacterial agent of infection/colonization. A total of 36 samples (circa 47\%) were found to be positive. Most often, samples taken from blankets were positive for S. aureus (88.9\%), followed by emergency/control buttons $(60.0 \%)$ and breathing hose poles $(54.5 \%)$. Other settings, such as respiratory tubes, mattress toppers, and dietary pumps were contaminated in every single case ( $n=3,2$ and 1, respectively) (Figure 1). Higher levels of contamination were found on sheets, pillows, buttons, and blankets. E. coli was not isolated in any of the surface samples.

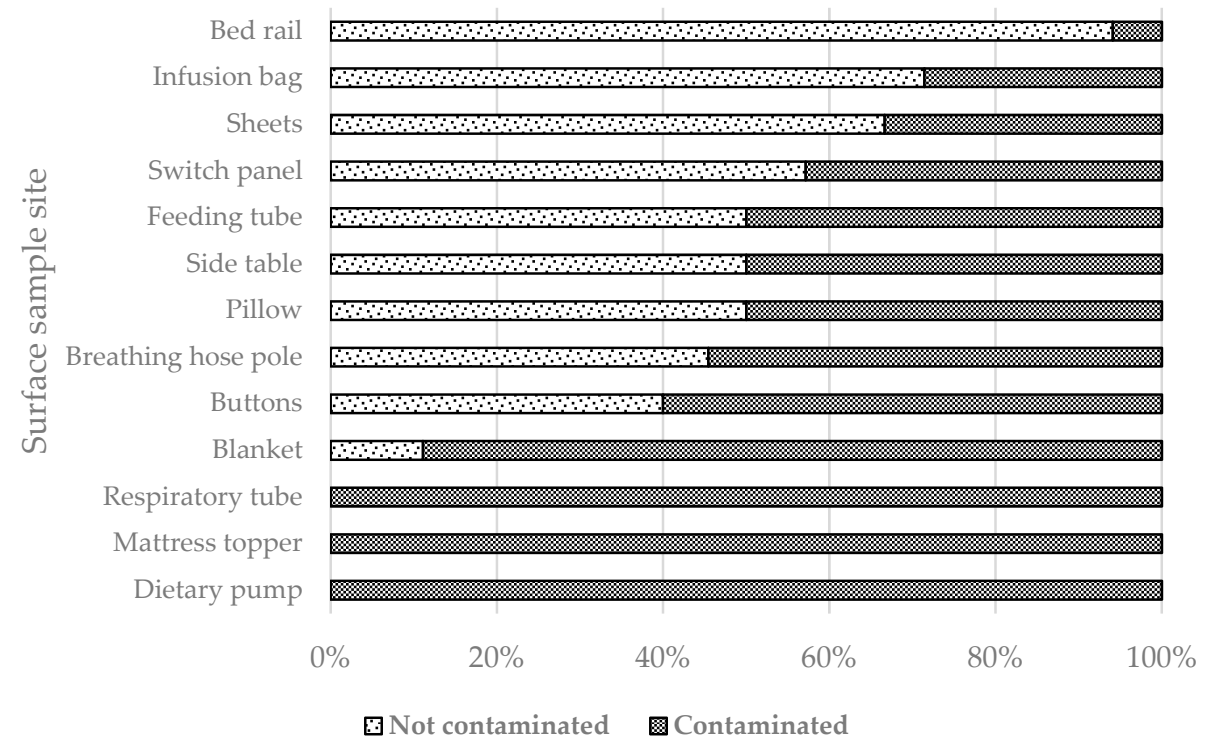

Figure 1. Staphylococcus aureus contamination of the environmental samples, according to the percentage of contaminated versus non-contaminated sites.

The majority of the colonies of $S$. aureus isolated from the environmental samples were resistant to at least one of the four antimicrobials tested $(n=128)$. Only 22 isolates were sensitive to all four antimicrobials. Of the resistant ones, 120 were multidrug resistant, of which 111 were resistant to two or three of the antibiotics tested and 9 were resistant to all four. Only 8 were resistant to only one antibiotic. Most S. aureus isolates were resistant to penicillin G (123 of 150 isolates), followed by erythromycin (100 out of 150), clindamycin (98 of 150), and tetracycline (16 of 150) (Figure 2).

Neither lytic bacteriophages lysing the indicator strains E. coli DSM 12242 nor S. aureus Sa9 were detected in any of the samples. 


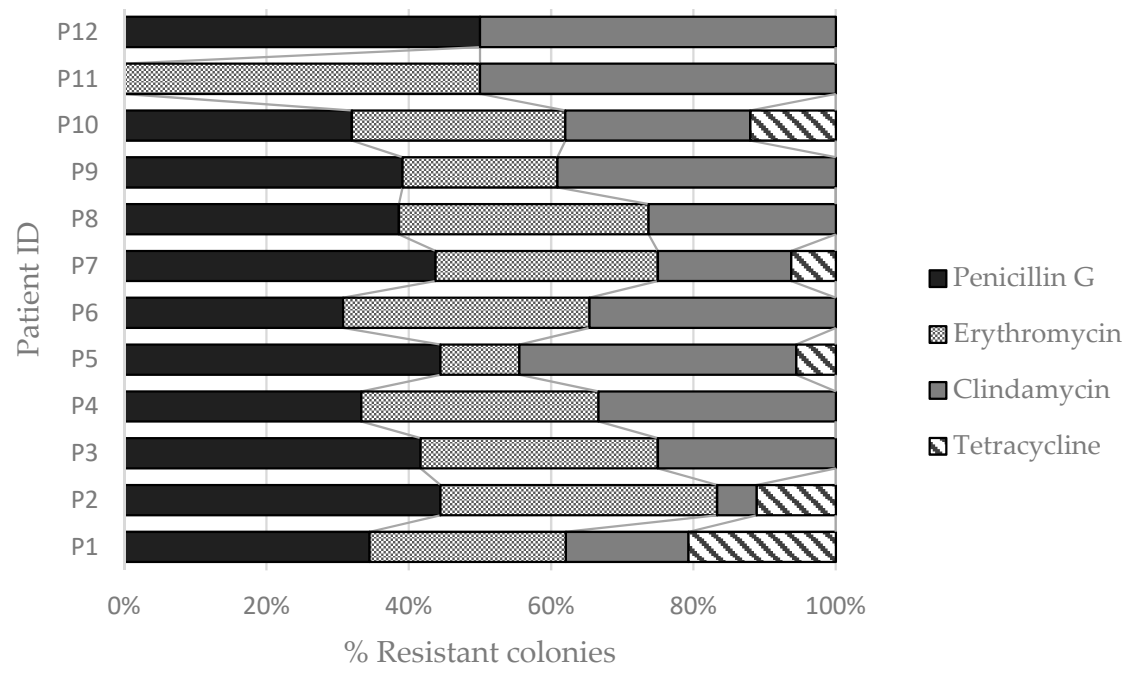

Figure 2. Percentage of environmental bacteria resistant to penicillin G, erythromycin, clindamycin, and tetracycline, found in the surroundings of each patient.

\subsection{Temperate Phages}

The presence of mitomycin C-inducible prophages was investigated in the 10 bacterial isolates collected (P1 to P10) and in a subset of 73 S. aureus isolates from the environmental samples. Of these, two of the patients' bacterial isolates contained mitomycin-inducible prophages, corresponding to an E. coli and an S. aureus isolate (P5 and P9, respectively). None of the isolates from environmental samples released phage particles spontaneously or upon mitomycin $C$ induction. The phages were purified by single-plaque propagation (Figure 3A,B) and named vB_EcoM_P5 and vB_SauS_P9. Phage vB_EcoM_P5 formed transparent, small, round plaques, approximately $0.3 \mathrm{~mm}$ in diameter on the lawn of E. coli DSM 12242, while phage vB_SauS_P9 formed rather small plaques of $0.1 \mathrm{~mm}$ under the conditions tested. Transmission electron micrographs of vB_EcoM_P5 (Figure 3C) and vB_SauS_P9 (Figure 3D) show phages with an icosahedral head of approximately $50-52 \mathrm{~nm}$. The coliphage has a tail of about $140 \mathrm{~nm}$, while the staphylococci phage has a longer tail of approximately $200 \mathrm{~nm}$. Based on virion morphology, vB_EcoM_P5 was classified as a Myoviridae family phage and vB_SauS_P9 as a Siphoviridae family phage (Figure 3C,D) [39].
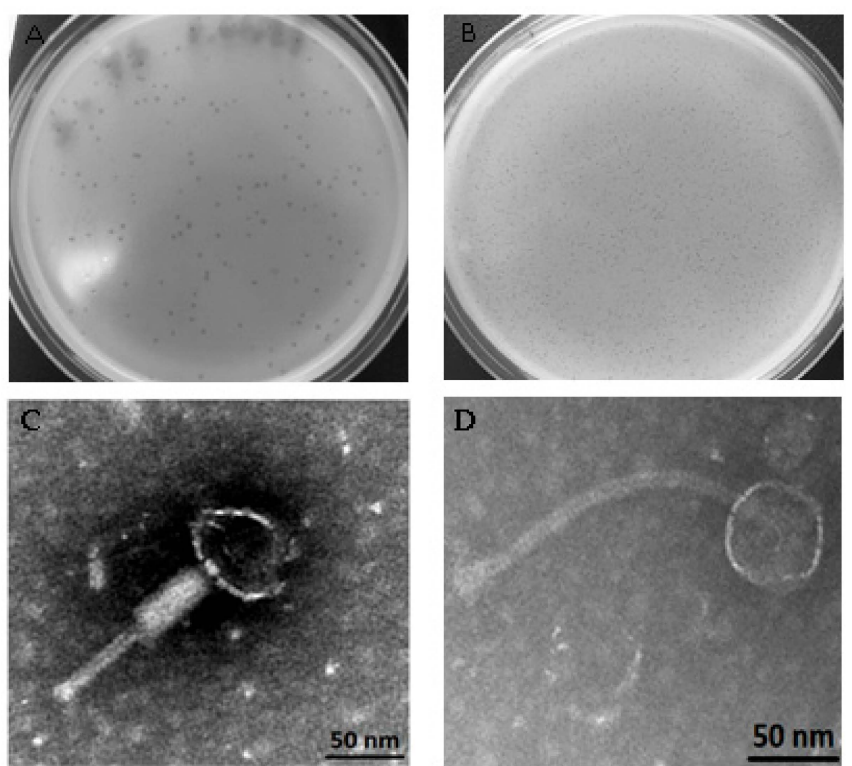

Figure 3. Plaque and virion morphologies of coliphage vB_EcoM_P5 (A,C) and staphylococci phage vB_SauS_P9 (B,D). 
Table 3. Antimicrobial activity of temperate phages vB_EcoM_P5 and vB_SauS_P9.

\begin{tabular}{|c|c|c|c|c|c|c|c|}
\hline \multicolumn{4}{|c|}{ vB_EcoM_P5 } & \multicolumn{4}{|c|}{ vB_SauS_P9 } \\
\hline Bacteria & Lysis & E.O.P. & Reference and/or Source & Bacteria & Lysis & E.O.P. & Reference and/or Source \\
\hline \multicolumn{4}{|c|}{ Culture collection strains } & \multicolumn{4}{|c|}{ Staphylococcus aureus from surface samples } \\
\hline Escherichia coli DSM 12242 & + & $1.000 \pm 0.000$ & DSMZ & Surface P1 (0/9) ${ }^{1}$ & - & - & Environment, this study \\
\hline Escherichia coli W3110 (ATCC 27325) & - & - & ATCC & Surface P2 (0/5) & - & - & Environment, this study \\
\hline Escherichia coli JM109 (DSM 3423) & + & $0.005 \pm 0.001$ & DSM & Surface P3 (0/4) & - & - & Environment, this study \\
\hline Escherichia coli DH5 $\alpha$ (DSM 6897) & - & - & DSM & Surface P4 (0/2) & - & - & Environment, this study \\
\hline Escherichia coli ATCC 11303 & - & - & ATCC & Surface P5 (7/11) & + & $0.142 \pm 0.080-0.781 \pm 0.219$ & Environment, this study \\
\hline Escherichia coli MC1061 (ATCC 53338) & + & $0.009 \pm 0.001$ & ATCC & Surface P6 (0/8) & - & - & Environment, this study \\
\hline $\begin{array}{l}\text { Klebsiella pneuтопіае sub. pneитопіае } \\
\text { ATCC } 13883\end{array}$ & - & - & ATCC & Surface P7 (7/7) & + & $0.000 \pm 0.000-0.001 \pm 0.000$ & Environment, this study \\
\hline $\begin{array}{l}\text { Yersinia enterocolitica sub. palearctica } \\
\text { DSM11502 }\end{array}$ & - & - & DSM & Surface P8 (7/11) & + & $0.000 \pm 0.000-0.013 \pm 0.009$ & Environment, this study \\
\hline $\begin{array}{l}\text { Salmonella enterica sub. enterica ATCC } \\
14028\end{array}$ & - & - & ATCC & Surface P9 (0/5) & - & - & Environment, this study \\
\hline $\begin{array}{l}\text { Salmonella typhimurium DT104 isolate } \\
\text { H3380 }\end{array}$ & - & - & Human [40] & Surface P10 (0/7) & - & - & Environment, this study \\
\hline \multicolumn{4}{|c|}{ Patient isolates } & Surface P11 (0/1) & - & - & Environment, this study \\
\hline E. coli isolate $19(\mathrm{P} 3)$ & - & - & Human, this study & Surface P12 (0/3) & - & - & Environment, this study \\
\hline E. coli isolate $33(\mathrm{P} 4)$ & - & - & Human, this study & \multicolumn{4}{|c|}{ Culture collection } \\
\hline E. coli isolate 46 (P5) & - & - & Human, this study & Staphylococcus aureus $\mathrm{Sa} 9$ & + & $1.0 \pm 0.00$ & Food, [36] \\
\hline K. pneumoniae isolate 76 (P7) & - & - & Human, this study & $\begin{array}{l}\text { Staphylococcus aureus } \\
\text { NCTC } 6571\end{array}$ & - & - & NCTC \\
\hline K. pneumoniae isolate 75 (P8) & - & - & Human, this study & \multicolumn{4}{|c|}{ Patient isolates } \\
\hline K. oxytoca isolate 89 (P10) & - & - & Human, this study & S. aureus isolate $11(\mathrm{P} 1)$ & - & - & Human, this study \\
\hline \multicolumn{4}{|c|}{ Clinical isolates } & S. aureus isolate $12(\mathrm{P} 2)$ & - & - & Human, this study \\
\hline \multirow[t]{3}{*}{ E. coli $(n=20)$} & - & - & Human, this study & S. aureus isolate $83(\mathrm{P} 9)$ & - & - & Human, this study \\
\hline & & & & \multicolumn{4}{|c|}{ Clinical isolates } \\
\hline & & & & $\begin{array}{l}\text { S. aureus isolate } 24 \\
\text { S. aureus isolates }(n=16)\end{array}$ & + & $\begin{array}{c}0.017 \pm \\
\pm \\
-\end{array}$ & $\begin{array}{l}\text { Human, this study } \\
\text { Human, this study }\end{array}$ \\
\hline
\end{tabular}

${ }^{1}$ Number of isolates showing lysis/number of isolates tested. 


\subsection{Lytic Spectrum}

The two phages were tested for the ability to lyse environmental bacteria and other clinical isolates collected during the study. Staphylococci-infecting phage vB_SauS_P9 lysed 45 of 150 environmental isolates collected from the patients' surroundings. The colonies were collected in the surroundings of P5, P7 and P8, all representing Enterobacteriaceae infections/colonizations. A higher sensitivity was found in the bacteria collected from the surroundings of patient $5(0.1 \leq \mathrm{EOP}<1.0)$. The remaining surface isolates were categorized as being low and inefficient producers, according to the calculated EOP. Of the seventeen S. aureus clinical isolates tested, only one was sensitive to phage vB_SauS_P9 $(\mathrm{EOP}=0.02)$. S. aureus isolate 24 was previously collected in the hospital. None of the $S$. aureus isolates $(n=3)$ from the 10 patients nor the culture collection strains $(n=2)$ tested showed signs of lysis (Table 3$)$. Phage vB_EcoM_P5 was tested in Enterobacteriaceae culture collection strains $(n=10)$, patient isolates $(n=7)$, and other clinical isolates previously collected $(n=20)$. It lysed culture collection strains $E$. coli JM109 and E. coli MC1061, but none was lysed as efficiently as E. coli DSM 12242. No lytic activity was observed against the clinical isolates tested.

\subsection{Antimicrobial Resistance Transduction}

The antibiogram from E. coli isolate P5 revealed resistance to ampicillin (Table 2). Phage vB_EcoM_P5 isolated originally from this strain was used to test its ability to transduce ampicillin resistance. After $48 \mathrm{~h}$, no transductants were observed.

Given that the antibiogram S. aureus isolate P9 (Table 2) was sensitive to all the antibiotics tested, vB_SauS_P9 was first propagated in two resistant (clindamycin, penicillin G and erythromycin) isolates from surface sample P5, determined as high and medium producers (Table 3). Propagation in an AB-resistant bacterium may encourage phage-harboring resistance genes and thereby transduce antimicrobial resistance. After phage propagation in these strains, transduction was attempted using the sensitive $S$. aureus $\mathrm{Sa} 9$ as a recipient. No transductants were obtained.

\subsection{Virucidal Effect of Disinfectants and Thermal Stability}

The hospital disinfectant TPH Protect is widely used to disinfect the surfaces around patients at a concentration of $0.5 \%(\mathrm{v} / \mathrm{v})$, according to hygiene measures applied in the facility. Half of this concentration was effective and inactivated vB_EcoM_P5 and vB_SauS_P9 after 15 min (Figure 4A). The coliphage was more stable to the disinfectant: vB_EcoM_P5 phage particles were still detected after $15 \mathrm{~min}(<0.1 \%$ survival), with total inactivation achieved after $30 \mathrm{~min}$. The same highly virucidal effect was observed for vB_SauS_P9 in the presence of $0.25 \%$ Hexaquart@plus ( $2 \%$ survival after $15 \mathrm{~min}$ and $0.2 \%$ after $60 \mathrm{~min}$ ). Coliphage vB_EcoM_P5 was better able to withstand the toxic conditions, displaying $34 \%$ survival after $15 \mathrm{~min}$ and $2 \%$ after $60 \mathrm{~min}$. Both phages were still detected when using 0.5\% Hexaquart@plus, but did not tolerate $70 \%$ ethanol. Phage vB_EcoM_P5 was generally more thermotolerant than staphylococci phage vB_SauS_P9 (Figure 4B), which is particularly evident at $55^{\circ} \mathrm{C}$, where phage counts were significantly reduced for vB_SauS_P9 $(<1 \%$ survival $)$, but vB_EcoM_P5 had a $92 \%$ viability. At $60^{\circ} \mathrm{C}$, all vB_SauS_P9 phage particles were inactivated. Phage vB_EcoM_P5 retained infectivity until $65^{\circ} \mathrm{C}(6 \%$ survival $)$, but was no longer detected at $70{ }^{\circ} \mathrm{C}$. 

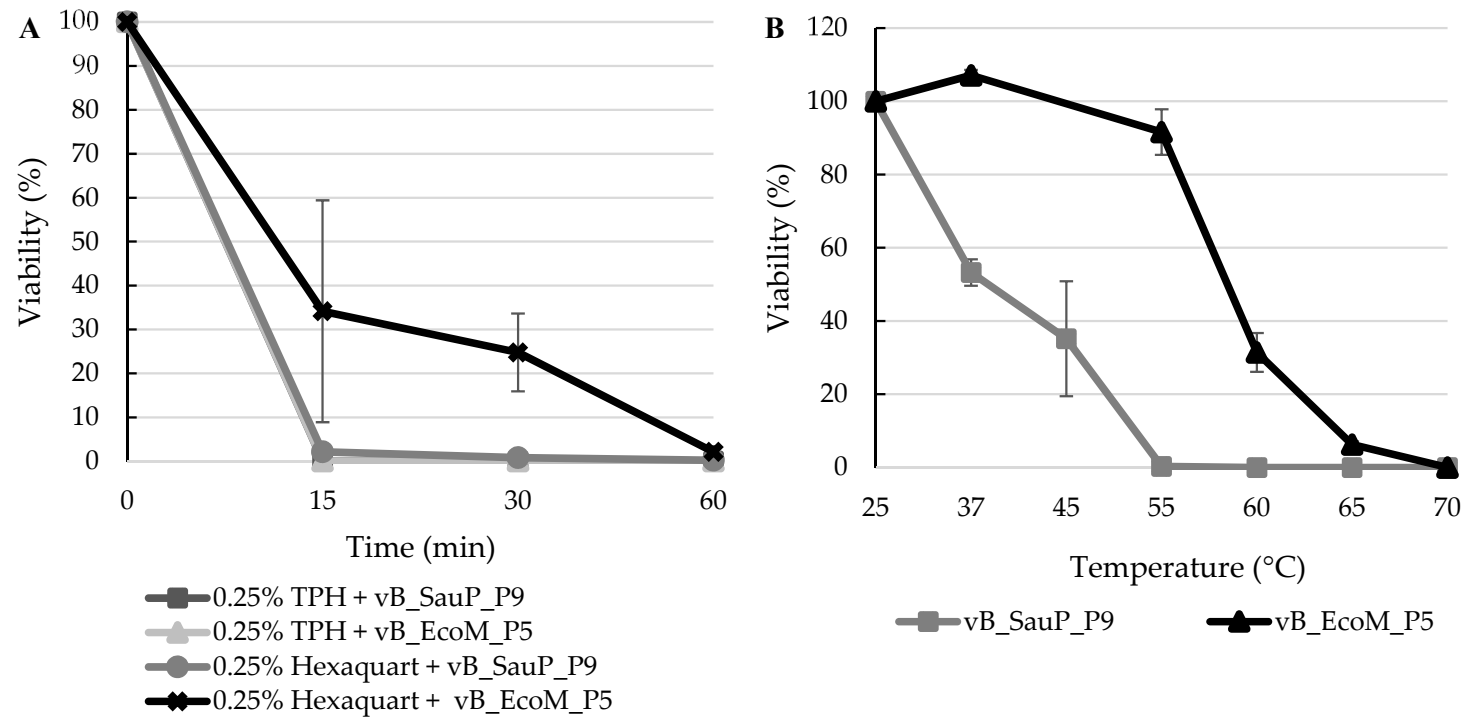

Figure 4. Stability of phages vB_EcoM_P5 and vB_SauS_P9 in the presence of disinfectants (A) and increasing temperatures (B).

\section{Discussion}

We present, to the best of our knowledge, the first study on the association between bacteriophages and bacteria in an ICU. Although S. aureus was found in the surroundings of all 12 patients and $47 \%$ of the samples were found to contain this species, no lytic phages were detected in any of the samples. The same result was obtained when testing for the presence of coliphages. Their apparent absence from clinical surfaces in the ICU might be associated with the lack of potential host $E$. coli, although it is possible that phages with a narrower host range remained undetected.

S. aureus is normally present in the flora of the human skin and is generally asymptomatic, although some strains are virulent and multidrug resistant $[1,3]$. Their occurrence is particularly problematic in an ICU, given the poor condition of patients-their increased vulnerability to infections and weakened immune systems $[1,3]$. A very high proportion $(80 \%)$ of the $S$. aureus isolated showed multidrug resistance and these bacteria were found on surfaces within close proximity to patients. Frequently touched surfaces are highly contaminated by hospital staff and/or infected patients [7,41,42]. Objects in close contact to the patients, including textiles such as bed linen, pillows, mattresses, and pajamas, also represent vehicles for the carriage of hair-, skin- and gut-associated bacteria, such as Staphylococcus spp. $[43,44]$. The bacteria are extremely resistant to desiccation [41], which partly explains their success as a colonizer of the ICU. There is a clear risk of direct or indirect patient-to-patient transmission, which could potentially aggravate patients' health. Antibiotic-resistant Staphylococcus sp. have been shown to be transmitted by aerosolization from bed linen during routine handling of bedding [43]. This possibility should be considered when identifying an appropriate disinfection routine, given the inherent resilience of staphylococci.

Despite the absence of lytic bacteriophages, two clinical isolates harbored mitomycin C-inducible prophages that were isolated and designated: vB_EcoM_P5 and vB_SauS_P9. These isolates came from urine obtained from a transurethral catheter and a blood culture. According to the 2016 Annual Epidemiological Report on healthcare-associated infections in ICUs in Europe, 97\% of the reported cases of pneumonia was associated with intubation, with bloodstream and urinary tract infections also largely caused by catheters (43.6\% and $99.3 \%$, respectively) [6]. The presence of temperate phages associated with the bacteria might affect the outcome of the infection. Naturally occurring bacteriophages in the medical environment drive the fitness of bacterial pathogens. Mediating the horizontal transfer of virulence and antimicrobial resistance determinants can lead to more aggressive bacterial pathogens and hence a demand for more complex treatments $[35,45,46]$. Prophages at the onset of sepsis have 
a role in clonal selection during bacterial invasion [12]. On the other hand, phages have attracted interest as potential biocontrol agents [47-49], and bacteriophage-based products may be effective at eliminating or reducing the bacterial load in critical settings, such as hospitals [50]. Bacteriophage aerosols have been suggested as a possible alternative adjuvant to conventional surface disinfection routines in the ICU and their use decreased the rates of infection caused by carbapenem-resistant Acinetobacter baumannii [50]. One of the phages we isolated, Staphylococcus phage vB_SauS_P9, lysed the vast majority of the isolates collected from the surface samples of three patients colonized/infected with Enterobacteriaceae (P5, P7, P8), which might be clonally related and possibly dispersed in the ICU around patient 5 . However, phage vB_SauS_P9 showed no activity against the clinical isolates tested.

We also investigated the possibility that these phages might act as vectors for horizontal gene transfer. Phages vB_EcoM_P5 and vB_SauS_P9 did not mediate the transfer of antimicrobial resistance from the selected donor bacteria to the sensitive host strains. The lack of appropriate selective pressure or genetic incompatibility of the mechanisms involved might have affected the generation of bacterial transductants. Despite their inability to transfer resistance determinants, the phages should not be regarded as safe for applications, given their temperate nature and possible integration in bacterial chromosomes [51].

We also tested the stability of phages vB_EcoM_P5 and vB_SauS_P9 to disinfectants. Staphylococci phage in the surgery suit of a horse clinic can persist after disinfection with Hexaquart $₫$ plus, which is based on a quarternary ammonium compound [52]. Such compounds have high efficiency against virulent dairy phages [53]. TPH Protect, the product used in the disinfection routine of the ICU we investigated, is a mixture of quaternary ammonium compounds and aromatic alcohol-based substances, with proven efficacy against enveloped viruses, Rotavirus and Norovirus [54]. Phage vB_EcoM_P5 was generally more thermotolerant and stable during disinfection than phage vB_SauS_P9. The phages were completely inactivated by $0.25 \%$ TPH Protect but could still be detected in $0.25-0.5 \%$ Hexaquart@plus. The phages were also unable to survive exposure to $70 \%$ ethanol, supporting the idea that a combination of alcohols and quaternary ammonium compounds can efficiently hinder viral activity. This practice, associated with the high frequency of disinfection in the ICU, might at least partly account for the absence of lytic phage particles in the surface samples.

Further investigation on the phages that inhabit the ICUs and their association with the bacteria living in this environment will help to understand phage ecology and critically assess phage applications in the future.

Author Contributions: Conceptualization, C.P. and F.H.; Data curation, C.P. and F.H.; Formal analysis, C.P., M.H., D.S., V.D., I.-J.P., C.A. and F.H.; Funding acquisition, F.H.; Investigation, C.P., M.H., D.S., I.-J.P. and C.A.; Methodology, C.P.; Project administration, F.H.; Resources, C.P., M.H., D.S., V.D., I.-J.P., C.A. and F.H.; Software, C.P., M.H. and V.D.; Supervision, F.H.; Validation, C.P.; Visualization, C.P. and M.H.; Writing - original draft, C.P.; Writing - review \& editing, C.P., M.H., D.S., V.D., I.-J.P., C.A. and F.H..

Funding: This work was in part supported by the NFB (Niederoesterreichische Forschungs- und Bildungsgesellschaft) grant number LS14-006. Open Access Funding Provided in Part by the University of Veterinary Medicine Vienna.

Acknowledgments: We are grateful to Pilar García Suáres and María Fernández García at the Instituto de Productos Lácteos de Asturias, Spanish National Research Council, for providing Staphylococcus aureus Sa9 and control phage Sa9 and to João Costa-Nunes and João Viana da Silva for critically reviewing the manuscript. We thank Graham Tebb for suggestions on the manuscript and language correction.

Conflicts of Interest: The authors declare that they have no conflict of interest.

\section{References}

1. Brusselaers, N.; Vogelaers, D.; Blot, S. The Rising Problem of Antimicrobial Resistance in the Intensive Care Unit. Ann. Intensive Care 2011, 1, 47. [CrossRef] [PubMed]

2. Russotto, V.; Cortegiani, A.; Raineri, S.M.; Giarratano, A. Bacterial Contamination of Inanimate Surfaces and Equipment in the Intensive Care Unit. J. Intensive Care 2015, 1-8. [CrossRef] [PubMed] 
3. Del Sorbo, L.; Marshall, J.C. Antibiotic Resistance in the Intensive Care Unit. In Intensive Care Medicine; Vincen, J., Ed.; Springer: New York, NY, USA, 2006; pp. 582-591. [CrossRef]

4. Vincent, J.; Marshall, J.; Anzueto, A.; Martin, C.D.; Gomersall, C. International Study of the Prevalence and Outcomes of Infection in Intensive Care Units. J. Am. Med. Assoc. 2009, 302, 2323-2329. [CrossRef] [PubMed]

5. Gastmeier, P.; Loui, A.; Stamm-balderjahn, S.; Hansen, S.; Zuschneid, I. Outbreaks in Neonatal Intensive Care Units-They Are Not Like Others. Am. J. Infect. Control 2007, 35, 172-176. [CrossRef] [PubMed]

6. European Centre for Disease Prevention and Control E. Annual Epidemiological Report for 2016 Healthcare-Associated Infections in Intensive Care Units; European Centre for Disease Prevention and Control E: Stockholm, Sweden, 2018.

7. Wertheim, H.F.L.; Melles, D.C.; Vos, M.C.; Leeuwen WVan Belkum AVan Verbrugh, H.A.; Nouwen, J.L. The Role of Nasal Carriage in Staphylococcus aureus Infections. Lancet Infect. Dis. 2005, 5, 751-762. [CrossRef]

8. Sampedro, G.R.; Wardenburg, J.B. Staphylococcus aureus in the Intensive Care Unit: Are These Golden Grapes Ripe for a New Approach? J. Infect. Dis. 2017, 215, S64-S70. [CrossRef]

9. Repessé, X.; Artiguenave, M.; Paktoris-Papine, S.; Espinasse, F.; Dinh, A.; Charron, C.; El Sayed, F.; Geri, G.; Vieillard-Baron, A. Epidemiology of Extended-Spectrum Beta-Lactamase-Producing Enterobacteriaceae in an Intensive Care Unit with no Single Rooms. Ann. Intensive Care 2017, 7, 73. [CrossRef]

10. Henderson, D.K. Managing Methicillin-Resistant Staphylococci: A Paradigm for Preventing Nosocomial Transmission of Resistant Organisms. Am. J. Infect. Control 2006, 119, S45-S52. [CrossRef]

11. ECDC. Healthcare-Associated Infections-A Threat to Patient Safety in Europe 2018. Available online: https://ecdc.europa.eu/en/publications-data/infographic-healthcare-associated-infections-threatpatient-safety-europe (accessed on 14 May 2019).

12. Gaidelyte, A.; Vaara, M.; Bamford, D.H. Bacteria, Phages and Septicemia. PLoS ONE 2007, 2, e1145. [CrossRef]

13. Sweere, J.M.; Van Belleghem, J.D.; Ishak, H.; Bach, M.S.; Popescu, M.; Sunkari, V.; Kaber, G.; Manasherob, R.; Suh, G.A.; Cao, X.; et al. Bacteriophage Trigger Antiviral Immunity and Prevent Clearance of Bacterial Infection. Science 2019, 363, eaat9691. [CrossRef]

14. Brussow, H.; Canchaya, C.; Hardt, W.-D. Phages and the Evolution of Bacterial Pathogens: From Genomic Rearrangements to Lysogenic Conversion. Microbiol. Mol. Biol. Rev. 2004, 68, 560-602. [CrossRef] [PubMed]

15. DeBardeleben, H.K.; Lysenko, E.S.; Dalia, A.B.; Weiser, J. Tolerance of a Phage Element by Streptococcus pneumoniae Leads to a Fitness Defect during Colonization. J. Bacteriol. 2014, 196, 2670-2680. [CrossRef] [PubMed]

16. Miller-Ensminger, T.; Garretto, A.; Brenner, J.; Thomas-White, K.; Zambom, A.; Wolfe, A.J.; Putonti, C. Bacteriophages of the Urinary Microbiome. J. Bacteriol. 2018, 200, 1-13. [CrossRef] [PubMed]

17. Navarro, F.; Muniesa, M. Phages in the Human Body. Front. Microbiol. 2017, 8, 1-7. [CrossRef] [PubMed]

18. Breitbart, M.; Hewson, I.; Felts, B.; Mahaffy, J.M.; Nulton, J.; Salamon, P.; Rohwer, F. Metagenomic Analyses of an Uncultured Viral Community from Human Feces. J. Bacteriol. 2003, 185, 6220-6223. [CrossRef] [PubMed]

19. Ackermann, H. Tailed Bacteriophages: The Order Caudovirales. Adv. Virus Res. 1999, 51, 135-201. [CrossRef]

20. King, A.; Adams, M.; Carstens, E.; Lefkowitz, E. Order-Caudovirales. Virus Taxon. 2012, 39-45. [CrossRef]

21. Krahn, T.; Wibberg, D.; Maus, I.; Winkler, A.; Bontron, S.; Sczyrba, A.; Nordmann, P.; Pühler, A.; Poirel, L.; Schlüter, A. Intraspecies Transfer of the Chromosomally Encoded Acinetobacter baumannii blaNDM-1 Carbapenemase Gene. Antimicrob. Agents Chemother. 2016, 60, 3032-3040. [CrossRef]

22. Billard-Pomares, T.; Fouteau, S.; Jacquet, M.E.; Roche, D.; Barbe, V.; Castellanos, M.; Bouet, J.Y.; Cruveiller, S.; Médigue, C.; Blanco, J.; et al. Characterization of a P1-Like Bacteriophage Carrying an SHV-2 Extended-Spectrum $\beta$-Lactamase from an Escherichia coli Strain. Antimicrob. Agents Chemother. 2014, 58, 6550-6557. [CrossRef]

23. Sekizuka, T.; Yamamoto, A.; Komiya, T.; Kenri, T.; Takeuchi, F.; Shibayama, K.; Takahashi, M.; Kuroda, M.; Iwaki, M. Corynebacterium ulcerans 0102 Carries the Gene Encoding Diphtheria Toxin on a Prophage Different from the C. diphtheriae NCTC 13129 Prophage. BMC Microbiol. 2012, 12, 72. [CrossRef]

24. Hendrix, R.W.; Smith, M.C.M.; Burns, R.N.; Ford, M.E.; Hatfull, G.F. Evolutionary Relationships among Diverse Bacteriophages and Prophages: All the world's a Phage. Proc. Natl. Acad. Sci. USA 1999, 96, 2192-2197. [CrossRef] [PubMed]

25. Hyman, P.; Abedon, S.T. Bacteriophages in Health and Disease, 1st ed.; CAB International: Oxfordshire, UK, 2012. 
26. Verkaik, N.J. Immune Evasion Cluster-Positive Bacteriophages are Highly Prevalent among Human Staphylococcus aureus Strains, but They Are Not Essential in the First Stages of Nasal Colonization. Clin. Microbiol. Infect. 2011, 17, 343-348. [CrossRef] [PubMed]

27. Arnold, C. Rethinking Sterile: The Hospital Microbiome. Environ. Health Perspect. 2014, 122, $182-187$. [CrossRef] [PubMed]

28. Mora, M.; Mahnert, A.; Koskinen, K.; Pausan, M.R.; Oberauner-Wappis, L.; Krause, R.; Perras, A.K.; Gorkiewicz, G.; Berg, G.; Moissl-Eichinger, C. Microorganisms in Confined Habitats: Microbial Monitoring and Control of Intensive Care Units, Operating Rooms, Cleanrooms and the International Space Station. Front. Microbiol. 2016, 7. [CrossRef] [PubMed]

29. Passaretti, C.L.; Otter, J.A.; Reich, N.G.; Myers, J.; Shepard, J.; Ross, T.; Carroll, K.C.; Lipsett, P.; Perl, T.M. An Evaluation of Environmental Decontamination with Hydrogen Peroxide Vapor for Reducing the Risk of Patient Acquisition of Multidrug-Resistant Organisms. Clin. Infect. Dis. 2013, 56, 27-35. [CrossRef] [PubMed]

30. Salgado, C.D.; Sepkowitz, K.A.; John, J.F.; Cantey, J.R.; Attaway, H.H.; Freeman, K.D.; Sharpe, P.A.; Michels, H.T.; Schmidt, M.G. Copper Surfaces Reduce the Rate of Healthcare-Acquired Infections in the Intensive Care Unit. Infect. Control Hosp. Epidemiol. 2013, 34, 479-486. [CrossRef] [PubMed]

31. Oberauner, L.; Zachow, C.; Lackner, S.; Högenauer, C.; Smolle, K.; Berg, G. The Ignored Diversity: Complex Bacterial Communities in Intensive Care Units Revealed by 16S Pyrosequencing. Sci. Rep. 2013, 3. [CrossRef] [PubMed]

32. Shousha, A.; Awaiwanont, N.; Sofka, D.; Smulders, F.J.M.; Paulsen, P.; Szostak, M.P.; Humphrey, T.; Hilbert, F. Bacteriophages Isolated from Chicken Meat and the Horizontal Transfer of Antimicrobial Resistance Genes. Appl. Environ. Microbiol. 2015, 81, 4600-4606. [CrossRef]

33. The European Committee on Antimicrobial Susceptibility Testing. Breakpoint Tables for Interpretation of MICs and Zone Diameters. Version 71 2017. Available online: http://www.eucast.org (accessed on 2 March 2017).

34. International Organization for Standardization. Water Quality_Detection and Enumeration of Bacteriophages. Part 2. Enumeration of Somatic Coliphages; ISO 10705-2:2000; ISO: Geneva, Switzerland, 2000; Volume 91.

35. Hilbert, M.; Csadek, I.; Auer, U.; Hilbert, F. Antimicrobial Resistance-Transducing Bacteriophages Isolated from Surfaces of Equine Surgery Clinics-A Pilot Study. Eur. J. Microbiol. Immunol. 2017, 7, $296-302$. [CrossRef]

36. García, P.; Madera, C.; Martínez, B.; Rodríguez, A.; Suárez, J.E. Prevalence of Bacteriophages Infecting Staphylococcus aureus in Dairy Samples and Their Potential as Biocontrol Agents. J. Dairy Sci. 2009, 92, 3019-3026. [CrossRef]

37. Groisman, E.A. In vivo Genetic Engineering with Bacteriophage Mu. Methods Enzymol. 1991, $204,180-212$. [CrossRef] [PubMed]

38. Salem, M.; Skurnik, M. Genomic Characterization of Sixteen Yersinia enterocolitica-Infecting Podoviruses of Pig Origin. Viruses 2018, 10, 174. [CrossRef] [PubMed]

39. Maniloff, J.; Ackermann, H. Taxonomy of Bacterial Viruses: Establishment of Tailed Virus Genera and the Order Caudovirales. Arch. Virol. 1998, 143, 2051-2063. [CrossRef]

40. Briggs, C.E.; Fratamico, P.M. Molecular Characterization of an Antibiotic Resistance Gene Cluster of Salmonella typhimurium DT104. Antimicrob. Agents Chemother. 1999, 43, 846-849. [CrossRef]

41. Pittet, D.; Allegranzi, B.; Sax, H.; Dharan, S.; Pessoa-Silva, C.L.; Donaldson, L.; Boyce, J. M Evidence-Based Model for Hand Transmission During Patient Care and the Role of Improved Practices. Lancet Infect. Dis. 2006, 6, 641-652. [CrossRef]

42. Fijan, S.; Turk, S.Š. Hospital Textiles, Are They a Possible Vehicle for Healthcare-Associated Infections? Int. J. Environ. Res. Public Health 2012, 9, 3330-3343. [CrossRef]

43. Handorean, A.; Robertson, C.E.; Harris, J.K.; Frank, D.; Hull, N.; Kotter, C.; Stevens, M.J.; Baumgardner, D.; Pace, N.R.; Hernandez, M. Microbial Aerosol Liberation from Soiled Textiles Isolated During Routine Residuals Handling in a Modern Health Care Setting. Microbiome 2015, 3. [CrossRef] [PubMed]

44. Hu, H.; Johani, K.; Gosbell, I.B.; Jacombs, A.S.W.; Almatroudi, A. Intensive Care Unit Environmental Surfaces are Contaminated by Multidrug-Resistant Bacteria in Biofilms: Combined Results of Conventional Culture, Pyrosequencing, Scanning Electron Microscopy, and Confocal Laser Microscopy. J. Hosp. Infect. 2015, 91, 35-44. [CrossRef] 
45. Marti, E.; Variatza, E.; Balcazar, J.L. Bacteriophages as a Reservoir of Extended-Spectrum Beta-Lactamase and Fluoroquinolone Resistance Genes in the Environment. Clin. Microbiol. Infect. 2014, 20, O456-O459. [CrossRef]

46. Allué-Guardia, A.; Imamovic, L.; Muniesa, M. Evolution of a Self-Inducible Cytolethal Distending Toxin Type V- Encoding Bacteriophage from Escherichia coli O157:H7 to Shigella sonnei. J. Virol. 2013, 87, 13665-13675. [CrossRef]

47. Górski, A.; Międzybrodzki, R.; Łobocka, M.; Głowacka-Rutkowska, A.; Bednarek, A.; Borysowski, J.; Jończyk-Matysiak, E.; Łusiak-Szelachowska, M.; Weber-Dabrowska, B.; Bagińska, N.; et al. Phage Therapy: What Have We Learned? Viruses 2018, 10, 288. [CrossRef] [PubMed]

48. Moye, Z.D.; Woolston, J.; Sulakvelidze, A. Bacteriophage Applications for Food Production and Processing. Viruses 2018, 10, 205. [CrossRef] [PubMed]

49. Wahida, A.; Ritter, K.; Horz, H. The Janus-Face of Bacteriophages across Human Body Habitats. PLoS Pathog. 2016, 12, e1005634. [CrossRef] [PubMed]

50. Ho, Y.-H.; Tseng, C.-C.; Wang, L.-S.; Chen, Y.-T.; Ho, G.-J.; Lin, T.-Y.; Wang, L.-Y.; Chen, L.-K. Application of Bacteriophage-Containing Aerosol against Nosocomial Transmission of Carbapenem-Resistant Acinetobacter baumannii in an Intensive Care Unit. PLoS ONE 2016, 11, e0168380. [CrossRef] [PubMed]

51. Philipson, C.W.; Voegtly, L.J.; Lueder, M.R.; Long, K.A.; Rice, G.K.; Frey, K.G.; Biswas, B.; Cer, R.Z.; Hamilton, T.; Bishop-Lilly, K.A. Characterizing Phage Genomes for Therapeutic Applications. Viruses 2018, 10, 188. [CrossRef] [PubMed]

52. Hilbert, M. Übertragung von Antibiotikaresistenzen von Phagen auf Bakterien im Veterinärmedizinischen Umfeld; Fachhochschule Wiener Neustadt: Wiener Neustadt, Austria, 2016.

53. Campagna, C.; Villion, M.; Labrie, S.J.; Duchaine, C.; Moineau, S. Inactivation of Dairy Bacteriophages by Commercial Sanitizers and Disinfectants. Int. J. Food Microbiol. 2014, 171, 41-47. [CrossRef] [PubMed]

54. Schuelke. TPH Protect n.d. Available online: https://www.schuelke.com/at-de/products/TPH-protect.php (accessed on 12 December 2016).

(C) 2019 by the authors. Licensee MDPI, Basel, Switzerland. This article is an open access article distributed under the terms and conditions of the Creative Commons Attribution (CC BY) license (http://creativecommons.org/licenses/by/4.0/). 